Swarthmore College

Works

Spring 2016

\title{
Symposium Introduction: Stepping Into Their Power: The Development Of A Teacher Leadership Stance
}

\author{
Lisa Smulyan , '76 \\ Swarthmore College, Ismulya1@swarthmore.edu
}

Follow this and additional works at: https://works.swarthmore.edu/fac-education

Part of the Education Commons

\section{Recommended Citation}

Lisa Smulyan , '76. (2016). "Symposium Introduction: Stepping Into Their Power: The Development Of A Teacher Leadership Stance". Schools: Studies In Education. Volume 13, Issue 1. 8-28. DOI: 10.1086/ 685800

https://works.swarthmore.edu/fac-education/92

This work is brought to you for free by Swarthmore College Libraries' Works. It has been accepted for inclusion in Educational Studies Faculty Works by an authorized administrator of Works. For more information, please contact myworks@swarthmore.edu. 


\title{
Symposium Introduction
}

\author{
Stepping into Their Power: The Development of a Teacher \\ Leadership Stance
}

\author{
LISA SMULYAN \\ Swarthmore College
}

\begin{abstract}
This is a movement about teachers stepping into their power. Make no mistake; we have powers that are vast and deep. We have accrued this power over the hours and days and years that we have spent with students. We have built it up over countless nights contemplating our students' lives. We have stifled it and shoved it down in staff meetings when we chose to "grin and bear it" rather than prolong a dreary and disheartening afternoon. We have shared it in brief moments of connection with our colleagues, rare moments that ignite our common strength and then flicker out as we rush back to our own isolated classrooms. We have hewn it out of mountains of ignorance. Teacher leadership is about harnessing this power that exists in every teacher, latent in some, obvious in others. It is about collecting this power and exercising it in ways that will make schools places that honor the critical perspectives and rich possibilities of teachers and students alike.

-Kathleen Melville, teacher leader and founding member of Teachers Lead Philly, July 3, 2013
\end{abstract}

Scott Storm, an English teacher, does action research in his classroom, and he has helped to start a new public school in New York City. Kathleen Melville teaches English and Spanish; she is a founding member of a teacher leadership group in Philadelphia that aims to bring teachers together to share ideas and contribute to district policy decisions. Maeve O'Hara, a math teacher, after hearing about a colleague's writing center in another school, started a math center at her school, in which student tutors help their peers do test corrections to demonstrate mastery of material. Over the course Schools: Studies in Education, vol. 13, no. 1 (Spring 2016).

(C) 2016 Francis W. Parker School, Chicago. All rights reserved. 1550-1175/2016/1301-0002\$10.00 
of several years, these teachers, and others like them, have come to see themselves as teacher leaders, not because of positions they hold or specific actions they have taken, but because they share a common stance within their schools, their districts, and the field of the education. This stance incorporates the following key perspectives:

- Teaching is a profession, which means it is growth-oriented, intellectual, and process-oriented.

- Teaching is a political act in the battle for social justice and democracy.

- Teaching is a collaborative process that includes networking within and across schools and districts with the goal of building relationships, understanding, political power, and knowledge that will ultimately improve the education of all children.

Our goal in this symposium is to present this approach to teacher leadership as a direct challenge to the prevalent discourses and policies that currently frame teachers' work. While we clearly build on the work of others in the field of teacher leadership, we do so with two goals, one educational and the other political. Our educational goal is to engage our peersteachers and teacher leaders - in thinking about how to continue to develop as the teachers they want to be. Our political goal is to contribute to, and begin to reshape, the dialogue about what constitutes good teaching. We want to make explicit how the current conversation positions teachers as either nameless cogs in a product-driven system or as those to blame for systemic failure. The teachers who share their work in the articles in this symposium speak back to neoliberal policies and practices, reframing the conversation about teaching in ways that provide a new understanding of professionalism, about teaching for social justice within a democracy, and about collaborating to more effectively engage in serving the common good.

\section{My Own Commitment}

I started teaching seventh-grade English and social studies in a public school in Brookline, Massachusetts, when I was 22 years old. Without knowing it, I fell into a teaching position that normalized, for me, the ideas that teaching is intellectual, collaborative, and political. Within my first three years, I had worked with other teachers to develop curricula that drew on a range of pedagogical approaches and content resources, and I had created several new programs for students within my school. At one point during my second year of teaching, I found and showed the movie With Babies and Banners, about women's roles in twentieth-century labor movements, to my seventhgraders. A student's mother contacted me to thank me for bringing gender 
issues into my class. Another mother accused me of being racist, because her son felt that I was not treating him fairly. Intellectual and collaborative endeavors, and the political nature of my daily decisions, were the norm in my early teaching career.

As a college professor for the past 30 years - an educator, researcher, and activist - I have worked to maintain this perspective on teaching in all that I do. It has, over time, become harder to engage undergraduates in a critical exploration of education and their potential roles within the field without having them throw up their hands in discouragement. The students note the entrenched and often worsening educational system that seems to benefit those with resources and continually undermine those without. Even the most dedicated students struggle to find ways to challenge policies that emphasize a market-based, privatized, test-driven approach to schooling and that deemphasize a commitment to democratic engagement challenge.

About 10 years ago, I worked with colleagues from the Consortium for Excellence in Teacher Education (CETE) to develop a program for new teachers. ${ }^{1}$ We knew that our teacher education programs were good but that new teachers needed support in order to grow and thrive once they reached their own classrooms. Our goal was to create a community for teachers where they could discuss their classroom practice; we also provided support services through professional development and mentoring. In Philadelphia, the New Teacher Network served, and continues to serve, about 15-20 new teachers each year.

Our work in this program, and our regular communication with alumni from our programs, led us to think about how to support more-experienced teachers, especially those who wanted to stay in the classroom but wanted an additional challenge or who struggled within the challenging context of public, especially urban, education. We knew that after their third year in the classroom, most teachers have attained tenure and report feeling competent and confident about their instruction. These second-stage teachers are particularly valuable to their schools because they have surmounted the challenges of classroom management and curriculum design and have attained greater expertise than novice teachers (Berry et al. 2010; Day 2000).

1. CETE was formed in 1983 with the initial goals of creating a support and exchange network for the teacher education programs at member colleges and to explore ways to ensure that preparation to teach remained a compelling option for undergraduates at our institutions. CETE member schools include Barnard College, Bates College, Bowdoin College, Brandeis University, Brown University, Bryn Mawr and Haverford Colleges, Connecticut College, Dartmouth University, Harvard University, Middlebury College, Mount Holyoke College, University of Pennsylvania, Princeton University, Smith College, Swarthmore College, Vassar College, Wellesley College, Wheaton College, and Yale University.

\section{Schools, Spring 2016}


As teachers enter this second stage, they become eager for opportunities to deepen their understanding of teaching and learning and to take on responsibilities beyond the confines of their own classrooms.

In 2010, four colleagues from other CETE institutions and I applied for and received a Ford Foundation grant to extend the work of the New Teacher Network to include more-experienced teachers. We invited 17 CETE alums from New York City, Boston, and Philadelphia to explore and develop their leadership capacities through a two-year program that included summer institute and regional meetings, which we describe in more detail below. In our grant application, we wrote, "The two-year program will provide the participants with a strong foundation for teacher leadership, while also creating a valuable cohort and support network as these teachers confront concrete challenges in their schools. Equipped with new skills and a framework about leadership, the participants will help to promulgate practitioner inquiry, engendering a culture of reflection and collaboration in their own schools."

We planned the first summer institute, but after that we let the teachers help us decide what was useful for them going forward. And so I was incredibly excited when the regional group of teacher leaders with whom I was working arrived at their statement of teacher leadership as a stance that incorporates professionalism, intellectual endeavors, collaboration, and a political commitment. I had created the program for new teachers and helped to develop this project on teacher leadership out of my conviction that work in public education is a profoundly civic enterprise and that teachers need support and opportunities to connect to one another and to others in the field in order to contribute to that enterprise. Although current political and institutional contexts work against these values and experiences, there are still teachers who choose to stay in the classroom and work for change. The project described below, out of which this symposium has developed, has created a space, an opportunity, and the support teachers need to continue to build on their own beliefs and to reframe the meaning of teacher leadership for themselves and others. I have been privileged to work alongside this group of teacher leaders who act on their commitments each day.

\section{Teacher Leadership: Prior Definitions and Research}

Much of the existing work on teacher leadership explores the skills and behaviors of teacher leaders in instructional, curricular, and policy arenas. Marya Levenson (2014), for example, explains, "Teachers are leaders when they act to improve instruction, strengthen the culture and organization 
of schools, or speak out on policies and practices that affect schools" (2). Johnson and Donaldson (2007) describe teacher leaders as teachers in the second stage of teaching (4-10 years of experience) who have developed management and curriculum development skills that leave them more available for other tasks and practices in their schools such as mentoring beginning teachers and chairing departments. These teachers take on new roles that allow them to collaborate with peers, often outside of their own classrooms. Katzenmeyer and Moller (2009) also describe teacher leadership as a role within the school, especially necessary at a time when schools face complex problems and changes. Teacher leaders look beyond their own classrooms; they "expand their circle of influence to all students and all teachers in our school-they are leaders of teachers and learners" (4). Teacher leaders take on substantive roles in their schools and, sometimes, their communities, in an effort to improve educational practice.

Explicitly or implicitly, much current work on teacher leadership is embedded in a neoliberal construction of education. Most broadly, neoliberalism redefines the relationships between society, institutions, and individuals, subjecting all to the requirements of a market system. Shifts in public education during the past 20 years exemplify a system that emphasizes market-based policy, privatization, individual effort, and efficiency (Apple 2001). Curricular reforms like No Child Left Behind and the Common Core Standards movement commodify education, reducing instruction to the teaching of bits of information and atomized skills (Shannon, Whitney, and Wilson 2014). Private (for-profit) companies, corporations, and foundations are encouraged to provide curriculum, tutoring, and school management services to struggling schools and districts (Ravitch 2010). Costs are reduced through economies of scale, leading to school closures, the abandonment of school libraries and art programs, and the minimization of curriculum, now focused primarily on responding to high-stakes tests (Ross and Gibson 2007). As control of resources and decision making about education shifts from the public to the private sectors, educational goals shift from democracy to profit and from the public good to the production of individual prosperity (Schniedewind 2011).

Within the neoliberal framework, teachers are often blamed for failing systems, and guidelines are developed to control and evaluate their work (Apple 2001; Singhal 2011). The neoliberal education policies described above strip teachers of control over curriculum and pedagogy and ask them to implement systems developed by others that are meant to maximize school efficiency and production. These policies also hold teachers "accountable" by measuring their success through high-stakes tests that do not con-

\section{Schools, Spring 2016}


sider the social, economic, and political constraints within which students and teachers are working. As Schniedewind (2011) argues,

One goal of a market-driven approach to education is to deprofessionalize the teaching profession, and its pay, by making teaching a routinized job rather than a field that requires a comprehensive education and ongoing professional development. Rather than being public intellectuals who teach young people how to think critically, solve problems creatively, and engage deeply with ideas, teachers will only need to follow a scripted curriculum geared toward passing standardized tests. Teachers will be trained quickly, paid little, and burn out, thus maintaining a revolving door of educators. (Schniedewind 2011, 19)

Berry, Byrd, and Wieder (2013) embed teacher leadership in this neoliberal framework within which individuals strive for success. These authors call for a fourth wave of teacher leaders, whom they call "teacherpreneurs." First-wave teacher leaders took on formal leadership roles, such as union representatives and department chairs. Second-wave teacher leaders took on instructional roles, implementing new curriculum, mentoring new teachers, and leading staff development workshops. Third-wave teacher leaders began to form and lead professional learning communities in order to create contexts within which teachers could continue to learn and grow. In the new fourth wave, teacherpreneurs stay in the classroom but also develop "big pedagogical and policy ideas and execute them in the best interests of both their students and their teaching colleagues" (16). The term teacherpreneurs, borrowed from a market-driven discourse, highlights the role of the individual in the process of bigger and better school improvement.

The emphasis on teacher leaders' individual behavior and skills is, perhaps, epitomized in the Model Teacher Leader Standards developed by the Teacher Leadership Exploratory Consortium (Teacher Leader Model Standards 2012), a group consisting of union representatives, school administrators, policy organizations, leaders in higher education, and a very few teachers. These standards cover seven domains, including

- understanding adults as learners to support professional learning communities

- accessing and using research to improves practice and student achievement

- promoting professional learning for continuous achievement

- facilitating improvements in instruction and student learning 
- using assessments and data for school and district improvement

- improving outreach and collaboration with families and community

- advocating for student learning and the profession

While these goals for teacher leaders may be valuable, the standards framework, developed by nonteachers, assumes that teacher action must be guided and controlled by others in order to ensure that teachers use the most effective and productive means to reach expected ends.

In this definitional work on teacher leadership, teacher leaders are described by the work they do and the roles they take. They are portrayed as individual actors within a competitive system, although they may work with others within or outside of their school. They may focus on pedagogy, curriculum development, school restructuring, professional development, or policy change. What emerges from this research is a sense of a fixed set of behaviors and roles and standards of performance that constitute teacher leadership.

The examination of individual teacher leaders in this literature has led some researchers to ask how teachers engage in leadership within specific contexts (Lieberman and Miller 2004). Thus, another existing body of literature examines the contexts that support or constrain the development of teacher leadership. Some of these studies explore the institutional and bureaucratic constraints that impact teachers' ability to practice their leadership skills. Lieberman and Friedrich (2010), for example, use vignettes written by teachers involved in the National Writing Project to describe how individual teachers learn a set of leadership practices through experience in their particular contexts. They explain that these teacher leaders acquire a "leadership identity" and learn how to build collegiality and community, manage conflict productively, and learn from practice through a process of reflection. Again, Lieberman and Friedrich (2010) suggest that teachers learn these skills on their own, through an individual process of trial and error, within particular contexts and through interactions with other teachers and administrators.

In a challenge to the individual framing of teacher leadership, some recent studies emphasize the importance of collaborative communities within which teachers can examine, practice, and develop the social and professional capital that will allow them to contribute to educational change (Hargreaves and Fullan 2012; Leana 2011; Lieberman and Miller 2004). Professional communities of practice become both the means for developing leadership abilities and the contexts within which teacher leaders can exercise those skills and contribute to individual and institutional change (Lieberman and Miller 2004).

\section{Schools, Spring 2016}


This symposium both extends and challenges some of this prior work on teacher leadership. Rather than defining leadership as a set of behaviors and skills within existing neoliberal political and institutional expectations about education, it explores the concept of leadership as a professional and political stance from which a wide variety of practices might emerge. Although the articles in this symposium do, in some cases, examine how collaboration and networks provide one context within which the stance develops, they demonstrate that the development of a leadership stance is organic rather than imposed and that it arises in many forms out of participation in multiple opportunities for conversation, practice, and reflection. The leadership stance that emerges is teachers' way of re-imagining society and the work they do within it.

\section{The Project behind the Stance}

In 2011, when the five college professors involved in this project organized our initial teacher leadership conference for the first cohort of 17 teacher leaders, we operated within definitions of teacher leadership from prior research. We assumed that teacher leadership consisted of skills and roles and that it could be nurtured within a professional community. We began with a week-long summer institute in 2011, at which we and the 17 teacher participants read about teacher leadership, discussed various definitions of teacher leadership, talked to seasoned educators about their experiences in the field of education, and engaged in workshops on mentoring colleagues and participating in or leading critical friends groups and other kinds of professional learning communities.

The project continued in the second year with smaller regional group meetings (in Philadelphia, New York City, and Boston), a full-group spring meeting to debrief experiences and participate in a workshop on teacher coaching, and a second, shorter, summer institute in 2012 that included some workshops on leadership skills but also examined options for continued group development and opportunities for teachers to write about their ongoing work. That second summer institute led to a spring 2013 meeting in New York City that was an original cohort group plus oneteachers each invited a colleague or two to join the meeting. At that meeting the group continued its conversations about developing leadership capacity and group sustainability. While at this point the original grant had been depleted, group members found ways to continue their work. I received funding from Swarthmore College to continue and expand a Philadelphia group. 
Members of the Boston group continued to meet and worked with a faculty member at Brandies University and preservice and novice teachers there. Several of the teachers became founding members of a new public school in New York City. And the original cohort has received funding from the Consortium for Excellence in Teacher Education to continue to meet for the next several summers as it explores opportunities to become sustainable and to develop teacher leadership cohorts in other areas of the country.

The university faculty involved in the project interviewed each of the K-12 participants twice, once during each of the summer institutes. I also maintained field notes of the various meetings and projects in which group members participated. Each teacher participant also completed online anonymous surveys following every group meeting during the first two years of the project. Teachers in the Philadelphia group, called Teachers Write Now (TWN), and I have met monthly for three years and have written informally about our work. This article is based on an analysis of interview data and field notes from the original cohort of 17 teacher leaders and on the written work of the Philadelphia group.

\section{The Development of a Teacher Leadership Stance}

In the course of a two-day writing retreat during our second year of working together, Scott Storm, a member of the original cohort of teacher leaders and of Teachers Write Now, explained that he had come to think of teacher leadership as a stance that informs all parts of his practice with students, colleagues, and those outside of education. When the project first started, he and others questioned what teacher leadership was and whether or not they qualified as teacher leaders. After participating in workshops on various skills and pathways to leadership, they came to see leadership as a set of behaviors (much as it is defined in a great deal of literature on teacher leadership) - mentoring, coaching, becoming an activist or department chair, doing critical friends or other collaborative teacher development projects, and conducting action research in their classrooms or schools. Eventually, teacher participants began to explain that teacher leadership was not just about what they did; it was not just a set of skills or behaviors that they could learn or teach to others. Teachers like Scott say that they have come to see teacher leadership as a stance, a way of being a teacher, that coalesces around being a professional, an intellectual, a fierce advocate for students and colleagues who ensures that everyone has the opportunity to learn and grow, and a collaborative member of a community dedicated to 
civic and social justice. They argue that no one could have taught them this stance; it developed through a process of interaction with others who shared their questions, their concerns, and their commitments. In the sections that follow, I explore how that stance developed.

The Start: Teacher Leadership as Behaviors and Skills

The teachers who applied to be a part of the original teacher leadership cohort funded by the Ford Foundation explained that they did so for several reasons. Some responded to an invitation from a college or university faculty member who had been a mentor during their undergraduate or graduate teacher education programs. They suggested that this personal connection was enough to get them to apply. Others described a need to explore next steps in their professional development given that they had been teaching for some time.

That same feeling of, "Okay, I have this itch to do something, and this matches exactly what I'm doing. I'm an urban teacher, I've been teaching for 8 plus years." . . . You know, it just seemed like the perfect match for me to narrow that focus or give me the skills or strategies to move forward, besides just saying, "I feel like I'm ready! What's next?" (Interview, August 2011)

I want to increase my sphere of influence on the community in general, and on the students in the community. ... I think that I care about the students in the community in which I teach, and I wantI feel like I have some good ideas that can help the folks there. (Interview, August 2011)

Others in the cohort had agreed to take on leadership positions in their schools - as department chairs, coaches, mentors for new teachers - and were looking for training to help them develop the confidence and skills needed to succeed.

The magic word that I said today was confidence. I'm taking on a lot of responsibility this coming year. I've had a lot of responsibility before, but this year, it just seems like a lot more, and I'm worried it's going to be like, "Hey, pay attention to me! I promise I'm in charge." (Interview, August 2011) 
I was hoping to gain practical knowledge around working with peers. Actually I made the decision to come to the institute before this position change.... So I was thinking, "Wow, this works out really well. I can get some practical understanding." (Interview, August 2011)

At this stage in the process, teachers' definitions of teacher leadership tended to focus on the knowledge and skills needed to work effectively within their schools, paralleling prior research in the field of teacher leadership. Teacher leadership encompassed a body of knowledge and skills that are important for all teachers but seemed to be even more important for teacher leaders.

[Teacher leaders need to be] super strong in terms of content knowledge; [have] knowledge of how to guide you in teaching and learning; and knowledge of culture and the impact and identity and the way that impacts the way people interact in general, but particularly in a school. Those are sort of the three categories that I say for all teachers; I think they're particularly important for teacher leaders. (Interview, August 2011)

\section{The Middle: Teacher Leadership as a Process}

During the second year of the program, teachers began to develop a new narrative, one that recognized the long-term commitment to and complexity of teacher leadership. They sometimes noted that they were learning to become more comfortable with leadership as a process rather than a set of skills. In an interview during the second summer institute, one teacher explained:

I tend to be goal-focused and I still have goals, but I seem to have relaxed more into enjoying the process in part because of this program. The issues that we are dealing with are very complex and realizing the degree to which I do and do not have control, and being okay with the things I don't have control of, seems to be what everybody here has discussed to some degree last year and this year. That was a big shift because I think a year ago I was very nervous about saying this is what I want to do next because I was worried, "What if I can't pull that exact thing off?" And I think I'm a little less afraid to say this is what I want to do next. (Interview, July 2012) 
At the closing meeting of that institute, another teacher commented:

The definition of teacher leadership has changed-it's a long-term process. We're not just faking being teacher leaders anymore; we're really leading now. (Field notes, July 2012)

These teachers also began to explore teacher leadership as a process that occurs in multiple contexts, broadening their sense of their own potential power.

I think that I took away from [the second summer conference] an appreciation or valuing of a long-term, process-driven approach to the changes I wanted to see in the school community, and the sense that it was transferrable within myself, that I wasn't so tied to a context. ... I am capable of being in multiple contexts and some of the skills or some of the pieces of leadership, because I heard them ... echoed by so many different people in so many different settings, it made me think that I was bigger than my setting and that I could be in multiple settings and be a leader, and also still face very similar challenges. (Interview, July 2012)

In addition, these teachers began to identify teacher leaders as active members of a profession, as educators with something to say in conversations about education. For example, one teacher commented: "We are thinking about teacher leadership now as having an impact on the profession. Being a teacher leader is more than being a department chair and leading the people in your school" (Field notes, July 2012). Teachers described professionalism as engaging with issues from a broad social and political frame of reference that included care and consideration of students, communities, and colleagues. In defining teacher leadership during the second summer, for example, one participant focused on leadership as a way of thinking and knowing within the field of education:

I think you need to be somebody who's always very reflective and questioning. And I think it's really important that you be somebody ... . who is asking questions a lot, and I think inevitably that leads to sort of looking at the bigger picture... . There's a way in which the role of the teacher has been defined to be very constricted or isolated or very in-the-classroom. And the teacher-leaders who inspire me the most are folks who are able to kind of look at the big picture and look at history 
and look at the way our society is changing and look for models in other contexts, other countries. (Interview, July 2012)

The Next Stage: Teacher Leadership as Stance

The teacher in the group who first referred to teacher leadership as a stance drew this idea from Marilyn Cochran-Smith and Susan Lytle's (2009) framework of inquiry as stance. Cochran-Smith and Lytle argue that an inquiry stance is "a worldview and a habit of mind - a way of knowing and being in the world of education that carries across educational contexts and various points in one's profession and that links individuals to larger groups and social movements intended to challenge the inequities perpetuated by the educational status quo" (viii). These scholars challenge the notion that inquiry is a professional development strategy or a skill teachers learn that allows them to become more effective practitioners of the status quo. Educators who take this stance commit to a collaborative, active, and engaged approach to their work, one that requires asking questions, gathering information, and acting upon new knowledge in ways that lead to classroom, school, and community development.

Teachers involved in the projects described here ultimately adopted the framework of teacher leadership as a stance for understanding and developing their work as teacher leaders. While they recognize the value of skill development and acknowledge the leadership roles they may play in their schools and districts, they have come to see leadership, like inquiry, as a world view, a positioning of oneself in the field of education. This stance incorporates the following interrelated key perspectives:

- Teaching is a profession, which means it is growth oriented, intellectual, and process oriented.

- Teaching is a political act in the battle for social justice and democracy.

- Teaching is a collaborative process that includes networking within and across schools and districts with the goal of building relationships, understanding, political power, and knowledge that will ultimately improve the education of all children.

These teacher leaders believe that teachers are professionals. They belong to a cohort of trained intellectuals who are concerned about their own growth, who have the resources and depth of understanding to control their own work, and who have important contributions to make to local, state, and national conversations about the field of education. They describe how 
their interactions with colleagues draw from their understanding of teaching as an intellectual profession:

I think a lot of what makes me feel like a teacher leader, and a lot of what makes other teachers treat me like a teacher leader, has to do with how I interact with other teachers. Namely, I try to look at the teachers around me like they are leaders as well. I look to colleagueseven (or especially) junior colleagues - for new approaches and teaching techniques. I ask for advice and perspective on children I feel stuck with. I encourage friends to write about their classroom experiences, to publish their techniques, to take their ideas to conferences. . . . There's a camaraderie and a respect built [among teachers] from shared hard work. But I sometimes feel there's a missing side of it - the respect that should exist, born of mutual experience as creators, as visionaries, as intellectuals. (TWN writing, March 16, 2014)

This teacher points out that collaboration alone may not be enough; collaboration must be grounded in a mutual respect for teachers' professionalism. In many of the contexts in which they work, they believe that they need to take a strong stance to demonstrate this professionalism to others and to convince a bureaucracy that they have significant contributions to make to student learning, professional development, and education within a democracy. One teacher, for example, described a professional development experience at his school at which a new assistant principal berated the teachers for not doing enough to improve student test scores. This teacher chose to speak up from his stance as a teacher leader:

I turned to the new AP and said, "You're attributing too much to these test scores." I claimed the students from the previous year were different from the ones the year before. They were the aberration. I suggested that, given all the cheating that has been exposed in the district, maybe we shouldn't believe every data point (knowing fullwell that there had been some cheating the year before last). I said, "Benchmark tests are poorly written, and we shouldn't put much stock in them." I said that he was making assumptions. That things were complicated. That things could be done, but ... that Study Island and more test prep weren't the answer, especially with high schoolers. I said, loud and clear, for everyone to hear, "You don't know what you're talking about." (TWN writing, September 25, 2013) 
The teacher leadership stance also incorporates a recognition of the political nature of teachers' work, both within and outside of their classrooms, and it explores how best to use this understanding to improve teaching, learning, and the role of education in our communities. These teachers are clear about the necessity of approaches to education that address social inequities and that contribute to a vibrant, critical democracy. At the classroom level, one teacher leader explored how she operationalizes this stance:

I am a leader because I am following my own beliefs about educating our students. In the past, I stressed about preparing my students for standardized tests. I feared that they would be unprepared or not show growth, and that this would in turn hurt how others saw me as a teacher. However, I never believed in the tests, and I never thought they could truly gauge the progress each student makes. Now, I focus on meeting my students where they are, helping them gain the skills they need to be productive and thoughtful adults, and not emphasizing the "test prep skills" they need for standardized tests. If the students do not perform well on the state standardized tests, I know that is not a reflection on my teaching. My students' progress, engagement, questions, and thoughts reflect my teaching. (TWN writing, March 16, 2014)

This political framing also involves teacher leaders seeing themselves as part of a broader community of actors. Just as the inquiry stance engages teachers with others who want to challenge the status quo, a leadership stance positions teachers as actors, with others, in a larger enterprise:

We need to see ourselves as responsible for leading education from the classroom, school, district, city, and societal levels. I do think that at every level, individuals working in education need to see themselves as educators. That is, teachers are not the only educators, but parents, principals, district leaders, and even politicians in charge of administering schools/deciding policies should share the same end goal of educating kids. I think that a true teacher leader sees all of these pieces as integral parts of the solution to creating better outcomes for kids. (TWN writing, September 25, 2013)

To me this means that a teacher who sees herself as a teacher leader has a unique view that is both deeply local and broadly political. Teachers are with children every day, doing the work, and learning and

\section{Schools, Spring 2016}


growth happen so very locally, in each relationship between teacher and student or among students, and so very incrementally, action and reaction, shifts in understanding and ability day to day. But teachers with this leadership stance, while holding themselves accountable for the important local, incremental work of educating each child, still keep a bigger picture in mind. They are aware of the impacts of institutional decisions not only on their own work but also on the work of their colleagues. They consider not just what is best for each particular student, but what promotes equity across the class, across the school, across the system. They consider not only how to overcome the impediments to their practice- - tired or hungry students, lack of funds for classroom materials - but how these impediments are the products of an inequitable system, and then they advocate for changes to that system. They consider how the learning that happens in secondgrade morning meeting or in eleventh-grade English may impact who their students become and what kind of change they, in turn, enact in the world. In other words, teachers with a teacher leader stance pour their hearts and souls into their students, but they don't lose sight of the context. (TWN writing, March 16, 2014)

These teacher leaders have found that part of what they seek, and what sustains their commitment to teaching as a profession and as a political process, is a genuine learning community. The collaboration that contributes to long-term professional development and school change requires a professional network of mentors and colleagues that can sustain and deepen intellectual and practical commitments. Teachers who have these opportunities can, in turn, provide for the effective learning of their students.

Being a teacher leader often means that I am saying "yes" to everything. Every meeting, every panel, every opportunity to network or plan. I have a responsibility to represent teachers and to raise a teacher voice. It's a reaction to the way in which teacher's work has been so circumscribed, how teachers are so hemmed in by the walls of their classrooms, isolated from the rest of the world, and anchored down by heavy workloads and lack of time. In my vision of the profession, teachers do work outside their classrooms, connected to policy makers and community organizations, sharing realities from the heart of education - the classroom. They have time to write and reflect, share and connect. Even though this vision is far from the reality right now, I try to live it as much as I can, to make the road by walking. (TWN, March 16, 2014) 
It makes sense, then, that the programming we provided for these teacher leaders, first through their teacher education programs, then through the summer institutes and follow up meetings, and later through the regional networks, led them to this aspect of the stance. While we know that communities of practice provide important contexts for teacher development (Hargreaves and Fullan 2012; Leana 2011; Lieberman and Miller 2004), we may underestimate the power of collaboration with like-minded peers to support teachers in the development and maintenance of their work as political, sustained professionals. If teacher leadership is seen as inherently interactive, political and collaborative, rather than the work of individual teachers each striving to support the system within a particular context, leadership cohorts and networks become central to the process of development and to the possibilities of change envisioned by these teachers.

\section{Conclusions: Stepping into Their Power}

When they began this leadership program, teachers articulated definitions of teacher leadership that mapped onto prior research in the field (e.g., Johnson and Donaldson 2007; Katzenmeyer and Moller 2009). They wanted to develop the skills and behaviors that would give them the confidence to assume roles within which they, as individuals, could improve student learning and teacher and school practice. In some ways, we all functioned early on within the given neoliberal definition of teacher leaders as teacherpreneurs - individuals who might improve student and teacher work within the current system. As a result of their participation in ongoing conversations and experiences with other teacher leaders, these teachers shifted to a perspective in which they described teacher leadership as a long-term professional and political commitment to a process of engagement with other educators across multiple contexts. Now, at this point in what is clearly an evolving process, teachers have developed an awareness of teacher leadership as a stance, one that incorporates an understanding of teaching as an intellectual, political, and collaborative profession.

This stance is a direct challenge to the neoliberal discourse and resultant policy that currently frames teachers' work and dominates the field of education (Brown 2003; Ross and Gibson 2007). Much of the work on neoliberalism and education has focused on market-driven institutional policies, such as vouchers and privatization, high-stakes testing to ensure future workers within a globally competitive economy, and teacher evaluation systems based on student test scores and "value added" computations (Apple 2001). Neoliberal policies and programs have successfully captured the

\section{Schools, Spring 2016}


discourse and framing of the teaching profession (Lipman 2011; Robertson 2007). Schniedewind (2011) argues, "Neoliberal initiatives systematically undercut the personal and professional knowledge of educators and force teachers to implement curriculum and employ pedagogy that may directly contradict their own understanding and beliefs about education and the students they teach" (10).

These teacher leaders, however, explore ways of re-imagining the work they do and how they will do it. They conceive of teaching, and teacher leadership, as an intellectual endeavor undertaken by politically attuned, active (and, when necessary, resistant) professionals who want to contribute to a more just and democratic society.

Through conversation, debate, writing, and working, teachers have developed this leadership stance within a collaborative network of diverse peers that has provided tools, role models, opportunities for reflection, and a deep respect for the work that they do. No one told them, "This is what you need to know and do in order to be a teacher leader." No one imposed upon them the need to think of themselves as both classroom teachers and agents of broader educational change. They developed these perspectives through the interactive processes they have come to believe are an imperative aspect of their work. They continue this work because they see it as a responsibility inherent in their positions as teacher leaders.

This project has implications for research, policy, and practice. Those who study teacher leadership must begin to recognize how neoliberal discourses and frames may be limiting our understanding of what constitutes teacher leadership. We need to listen to teachers and recognize that leadership is a developmental path within a dynamic and contested profession. Listening to teachers narrate their power will allow researchers to hear and communicate discourses that reframe our understanding of teacher leadership as more than individual roles and skills. Leadership is a way of being a teacher that implies connection to larger professional and political goals and processes. Exploring this kind of leadership requires a consciousness of prior frameworks that may, in fact, be contributing to narratives of teachers as cogs in the wheel of a system that works to disempower them. Researchers need to engage with teachers and teacher leaders in ways that allow us to hear how teachers can contribute to individual, institutional and political change.

This study also illustrates how providing opportunities for teachers to reflect, take risks, share experiences, and explore options for growth within a supported community can lead to the development of a leadership stance. Growth into this stance occurs through a gradual narrative process, which 
suggests that teachers need sustained space, time and support to examine and develop an understanding of leadership. The programs described in this paper provided one set of these opportunities; professional communities of practice within and outside of schools have begun to provide others (see, e.g., Baker-Doyle 2011). While schools, districts, and outside organizations can provide the necessary resources, teachers themselves will, given the opportunity, provide the substance and direction of a movement toward teacher leadership.

The articles that follow are the first in what we hope will be an ongoing symposium of writing by teachers who have been involved in one or more of the teacher leadership programs described above. In this issue, Kathleen Melville explores her own development as a teacher leader. She reflects on how her search for collaboration led her outside of her own school context, into several teacher leadership groups (one of which she helped to start), and then back into a new, teacher-led school within which she can exercise many of her values and goals as a teacher leader. Scott Storm, too, explores his own personal and professional trajectory. He describes his experience as an individual trying to act on - and share with others - his beliefs about teaching as an intellectual and political process, his participation in outside of school teacher leadership communities, and his current involvement in a school which has welcomed his leadership. Stacey Carlough has taught in her school for 10 years, a school that has neither actively supported nor worked against Stacey's development of a leadership stance. During those 10 years, Stacey has found several ways to carve out opportunities to collaborate with students and fellow teachers. Most recently, in the development of a new mentoring position, Stacey has created the possibility of building a more collaborative and professional culture of teacher learning within a fairly individualistic (and sometimes sink or swim) institutional context. Each of these teacher leaders demonstrates the possibilities and challenges of pursuing a professional, political, and collaborative approach to teaching and leading.

\section{References}

Apple, Michael. 2001. Education the "Right" Way: Markets, Standards, God, and Inequality. New York: RoutledgeFalmer.

Baker-Doyle, Kira. 2011. The Networked Teacher. New York: Teachers College Press.

Berry, Barnett, Ann Byrd, and Alan Wieder. 2013. Teacherpreneurs: Innovative Teachers Who Lead but Don't Leave. Hoboken, NJ: Wiley. 
Berry, Barnett, Alesha Daughtrey, and Alan Wieder. 2010. Preparing to Lead an Effective Classroom: The Role of Teacher Training and Professional Development Programs. Hillsborough, NC: Center for Teaching Quality.

Brown, Wendy. 2003. "Neo-liberalism and the End of Liberal Democracy." Theory and Event 7 (1): 1-25.

Cochran-Smith, Marilyn, and Susan Lytle. 2009. Inquiry as Stance: Practitioner Research for the Next Generation. New York: Teachers College Press.

Day, David V. 2000. "Leadership Development: A Review in Context." Leadership Ouarterly 11 (4): 581-613.

Hargreaves, Andrew, and Michael Fullan. 2012. Professional Capital: Transforming Teaching in Every School. New York: Teachers College Press.

Johnson, Susan Moore, and Morgaen L. Donaldson. 2007. "Overcoming the Obstacles to Leadership." Educational Leadership 65 (1): 8-13.

Katzenmeyer, Marilyn, and Gayle Moller. 2009. Awakening the Sleeping Giant: Helping Teachers Develop as Leaders. Thousand Oaks, CA: Corwin.

Leana, Carrie R. 2011. "The Missing Link in School Reform.” Stanford Social Innovation Review 9 (Fall): 30-35.

Levenson, Marya. 2014. Pathways to Teacher Leadership: Emerging Models, Changing Roles. Cambridge, MA: Harvard Education Press.

Lieberman, Ann, and Linda D. Friedrich. 2010. How Teachers Become Leaders: Learning from Practice and Research. New York: Teachers College Press.

Lieberman, Ann, and Lynne Miller. 2004. Teacher Leadership. San Francisco: Jossey-Bass.

Lipman, Pauline. 2011. The New Political Economy of Education. New York: Routledge.

Ravitch, Diane. 2010. The Death and Life of the Great American School System: How Testing and Choice Are Undermining Education. New York: Basic Books.

Robertson, Susan L. 2007. "'Remaking the World': Neo-liberalism and the Transformation of Education and Teachers' Labour." In The Global Assault on Teachers, Teaching and Their Unions, ed. Lois Weiner and Mary Compton. New York: Palgrave.

Ross, Wayne, and Rich Gibson. 2007. Neoliberalism and Education Reform. Cresskill, NJ: Hampton.

Schniedewind, Nancy. 2011. "A Short History of the Ambush of Public Education." In Educational Courage: Resisting the Ambush of Public Education, ed. Nancy Schniedewind and Mara Sapon-Shevin. Boston: Beacon.

Symposium / Lisa Smulyan 27 
Shannon, Patrick, Anne Elrod Whitney, and Maja Wilson. 2014. "The Framing of the Common Core State Standards." Language Arts 91 (4). Singhal, Neha. 2011. "Why I Quit Teach for America to Fight for Public Education." In Educational Courage: Resisting the Ambush of Public Education, ed. Nancy Schniedewind and Mara Sapon-Shevin. Boston: Beacon.

Teacher Leader Model Standards. 2012. Teacher Leadership Exploratory Consortium. http://www.teacherleaderstandards.org/teacher_leadership _exploratory_consortium. 